Original Article

\title{
ANTI-TUMOUR ACTIVITY OF BROMOPYRROLE ALKALOIDS AGAINST HUMAN BREAST TUMOUR (MCF-7) THROUGH APOPTOSIS INDUCTION
}

\author{
S. MANIKANDAN1-2*, S. GANESAPANDIAN³, MANOJ SINGH1, 4 , A. K. KUMARAGURU1
}

1Department of Marine and Coastal Studies, School of Energy, Environment and Natural Resources, Madurai Kamaraj University, Madurai 625021, Tamilnadu, India, ${ }^{2}$ Whale India Foundation, Ramanathapuram 623503 , Tamilnadu, India, ${ }^{3}$ Government Higher Secondary School, Kadukkai valasai, Ramanathapuram District, Tamilnadu, India, ${ }^{4}$ Department of Biotechnology, MMEC, Maharishi Markandeshwar

(Deemed to be University), Mullana 133207, Haryana, India

Email; micromanismk@gmail.com

Received: 12 Aug 2018 Revised and Accepted: 02 May 2019

\section{ABSTRACT}

Objective: The present study was conducted to screen the cytotoxicity and initiation of apoptosis in MCF-7 human breast tumour cells using the Indian sponge Acanthostylotela cornuta of the Gulf of Mannar.

Methods: The crude methanol extract of $A$. cornuta was fractionated using a reversed phase silica gel column chromatography. The purity of the active fraction of bromopyrrole alkaloids was confirmed with Gas Chromatography-Mass Spectrometry (GCMS). The bromopyrrole alkaloids induce apoptotic changes in MCF-7 cells were studied with electrophoresis, caspase assay, and different staining analysis. The MCF-7 cells were analyzed by Flow cytometry to determine their DNA content.

Results: Bromopyrrole alkaloids of $A$. cornuta showed cytotoxicity against MCF-7 human breast tumour cells with the IC 50 value of $8.0 \mu \mathrm{g} / \mathrm{ml}_{\text {. }}$ The bromopyrrole compounds induced cells exhibited scatted red fluorescence, showing the presence of several residual bodies and condensation of chromatin. Caspase-3, pro-caspase-9, caspase-9 and Poly-ADP-Ribose-Polymerase (PARP) activity were occurred in bromopyrrole alkaloids treated tumour cell. The cell cycle arrest is conceivable that the compound prevented the progression of cell cycle through the $\mathrm{G}$ phase resulting from inhibition of survival, leading them to undergo apoptosis.

Conclusion: Bromopyrrole alkaloids of $A$. cornuta possess antitumor activity which was arrested the $\mathrm{G}$ phase in cell cycle that clearly indicated its nature as that of antitumour drugs.

Keywords: Marine sponge, Acanthostylotela cornuta, Antitumour, Breast tumour, Apoptosis

(C) 2019 The Authors. Published by Innovare Academic Sciences Pvt Ltd. This is an open-access article under the CC BY license (http://creativecommons.org/licenses/by/4.0/) DOI: http://dx.doi.org/10.22159/ijpps.2019v11i6.29092

\section{INTRODUCTION}

Tumour is considered as one of the most serious threats to humankind. Annually, it causes more than $13 \%$ of all human deaths, among them, $70 \%$ of all tumour deaths occurred in low and middleincome countries. WHO estimates of death due to tumour worldwide are an estimated 12 million deaths in 2030. Breast tumour is the most common in women and one-third of the women with breast tumour develop metastases that ultimately results in death. In 1970, the MCF7 cell line was noticed after that MCF-7 cell has become a prominent model system for the study of breast tumour. Most of the tumors initially respond to chemotherapy, similarly breast tumour cells can subsequently survive and gain resistance to the chemo treatment [1$3]$. The discovery of new antitumor drug with low side effects on the human system has become an essential goal in many studies.

Marine organisms are the rich sources of structurally novel and biologically active metabolites. So far, many unique compounds of marine origin with different biological activities have been isolated and a number of them are under investigation [4-7]. The discovery of antitumor drugs derived from natural marine products has enjoyed in the past few years, especially after the approval of trabectedin [8]. As the first marine-derived antitumor drug to reach the market, trabectedin was first identified to be a tetrahydroisoquinoline alkaloid derived from a Caribbean tunicate in 1990 [9]. Alkaloids of marine origin are widely distributed in marine sponges with widespread biological activity [10].

Screening of organic solvent extracts from marine sponges and other marine organisms is a common approach to identify compounds of biomedical importance. Marine sponges have been considered as a goldmine during the past $50 \mathrm{y}$, with respect to the diversity of their secondary metabolites. The biological effects of new metabolites from sponges have been reported in many scientific papers. Sponges have the potential drugs of the future to act against important diseases, such as tumour, a range of viral diseases, malaria and inflammations. In recent years, there has been an increased need for new chemotherapeutic agents, as the emergence of drug resistance in tumour poses a significant clinical problem. The present study was conducted to screen the cytotoxicity and initiation of apoptosis in MCF-7 breast tumour cells using the Indian sponge Acanthostylotela cornuta of the Gulf of Mannar.

\section{MATERIALS AND METHODS}

Chemicals, reagents and solution

Methanol, phenol, chloroform, isoamyl alcohol and propidium iodide were purchased from Sigma-Aldrich. All statins were obtained from Himedia. Geno Technology provided RNase, agarose and ethidium bromide.

\section{Collection and extraction of the marine sponge}

Marine sponge A. cornuta from the Gulf of Mannar, southeast coast of India were collected and identified based on the identification characters given by Thomas 1998 [11]. Sponge was rinsed with sterile distilled water, cut into small pieces, air dried at room temperature for $4 \mathrm{~d}$, weighed and repeatedly extracted with methanol. The extracts were kept overnight in a refrigerator and filtered. All solvent extracts were pooled evaporated and concentrated in a rotary vacuum evaporator under reduced pressure. The crude extract was used for cytotoxicity assay [12] against MCF-7 breast tumour cells (MCF-7 was obtained from the National Center for Cell Science, Pune, India).

\section{Column fractionation}

The crude methanol extract of $A$. cornuta was fractionated using reversed phase silica gel column chromatography (230-400) with a column size of $43 \times 2 \mathrm{~cm}$ using a step gradient of increasing polarity 
from hexane to acetone to methanol. The different column fractions were collected and the purity of the active fraction was confirmed by Gas Chromatography-Mass Spectrometry (GCMS) library. Each fraction was used for cytotoxicity against MCF-7 breast tumour cells with $10 \mu \mathrm{g} / \mathrm{ml}$ concentration.

\section{DNA fragmentation}

Bromopyrrole compounds treated cells as well the untreated cells of 106cells were pelleted and re-suspended in $1 \mathrm{ml}$ of lysis buffer for cellular DNA extraction by proteinase $\mathrm{K}$ digestion [13]. The mixture was incubated overnight at $55{ }^{\circ} \mathrm{C}$ and then at $37{ }^{\circ} \mathrm{C}$ for $30 \mathrm{~min}$ with 0.25 $\mathrm{mg} / \mathrm{ml}$ of RNase. DNA was extracted by phenol: chloroform: isoamyl alcohol (25:24:1) mixture, precipitated in ethanol and loaded on a $2 \%$ Agarose gel containing ethidium bromide $(0.6 \mu \mathrm{g} / \mathrm{ml})$, at 80 Volts. The gels were then photographed under UV light.

\section{Cell cycle analysis}

Bromopyrrole compounds treated and untreated MCF-7 cells were harvested and centrifuged at $3000 \mathrm{rpm}$ for $3 \mathrm{~min}$ at $4{ }^{\circ} \mathrm{C}$. The cells were washed once with cold PBS (phosphate buffer saline) and harvested again by centrifugation under the same condition. Then, $150 \mu \mathrm{l}$ of propidium iodide in water solution (propidium iodide $50 \mu \mathrm{g} / \mathrm{ml}$, sodium citrate $0.1 \%$ and nonidet P- $400.2 \%$ ) was added into each tube and the cells were stained at $4{ }^{\circ} \mathrm{C}$ for $30 \mathrm{~min}$. Then the cells were analyzed by Flow cytometry to determine their DNA content (using the computing system, XLII (Coulter)).

\section{Annexin-V staining}

Bromopyrrole compounds treated MCF-7 cells were harvested by $0.25 \%$ trypsin-EDTA digestion, washed in serum-free DMEM, and stained by incubation with Annexin-V-Fluos label solution at $37^{\circ} \mathrm{C}$ for $15 \mathrm{~min}$. The label solution was prepared shortly before use by prediluting $20 \mu \mathrm{l}$ Annexin-V-fluorescein isothiocyanate (FITC) (Roche Molecular Biochemicals) and $20 \mu \mathrm{l}$ of $50 \mu \mathrm{g} / \mathrm{ml}$ propidium iodide in $1 \mathrm{ml} \mathrm{Hepes}$ buffer. Staining cells simultaneously with FITC-Annexin-V (green fluorescence) and the non-vital dye propidium iodide (red fluorescence) allows (bivariate analysis) the discrimination of intact cells (FITC-PI-), both early apoptotic (FITC+PI-) and late apoptotic (FITC+PI+).

\section{Hoechst staining}

Bromopyrrole compounds treated and untreated cells were harvested by centrifugation; the obtained pellet was resuspended in $1 \mathrm{ml} \mathrm{PBS}$. Each sample was stained with $10 \mu$ l Hoechst solution (dissolved in double distilled water at a stock concentration of $0.1 \mathrm{mg} / \mathrm{ml}$ ) for $5 \mathrm{~min}$ at $37{ }^{\circ} \mathrm{C}$ in the dark. The dye was removed by centrifugation (110xg; $10 \mathrm{~min} ; 4$ ${ }^{\circ} \mathrm{C}$ ) and washing with PBS. Condensed chromatin was visualized by confocal laser scanning microscopy.

\section{Propidium iodide staining}

Propidium iodide is used as a marker of cell death and as well as for analysis of nuclear morphology of dead cells. Bromopyrrole compounds treated cells were stained with propidium iodide $(20 \mu \mathrm{g} / \mathrm{ml}, 5 \mathrm{~min})$ on glass coverslips. The cells were visualized by confocal laser scanning microscopy and apoptotic nuclei were observed.

\section{Determination of caspase activity}

Caspase activation was measured using a caspase colorimetric assay kit as described by the manufacturer (Geno Technology). Cultured monolayer of cells in the dishes was exposed to $1 \mathrm{ml}$ of MEM medium containing defined different concentrations of the bromopyrrole compounds then protein was estimated using

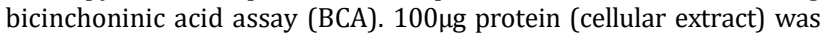
diluted in $50 \mu \mathrm{l}$ cell lysis buffer and then incubated in 96-well microtiter plates with $5 \mu \mathrm{l}$ of the $4 \mathrm{mmol}$ p-nitroanilide (pNA) substrates (DEVD-pNA for caspase-3 activity and Ac-LEHD-pNA for caspase- 9 activity) for $2 \mathrm{~h}$ at $37^{\circ} \mathrm{C}$. Caspase activity was measured by cleavage of the substrates to free pNA. Free pNA (cleaved substrates) was measured by absorbance at $405 \mathrm{~nm}$ in a microtiter plate reader. Relative caspase- 3 and caspase- 9 activities were calculated.

\section{Western blotting analysis}

$20 \mu \mathrm{g}$ aliquots of protein extracts from bromopyrrole compounds treated and untreated MCF-7 cells were separated on 10\% SDS polyacrylamide gels. After electrophoresis, the proteins were blotted onto polyvinylidene difluoride membranes (PVDF). The membranes were blocked with 5\% non-fat milk in PBS plus $0.1 \%$ Tween-20 and then incubated with primary antibodies (monoclonal rabbit anti-PARP) to the Poly-ADPribose-polymerase (PARP). The secondary antibody (anti-mouse coupled to horse-radish peroxidase) was added (1:2000 dilution) and kept for $1 \mathrm{~h}$ at room temperature. Finally, the protein was visualized using the ECL detection kit (Amersham) and exposing the membranes to X-ray film (HYPERFILMTM, Amersham).

\section{Cell viability assay}

This assay is a quantitative colorimetric method for the determination of cell survival and cytotoxicity. The crude methanol extract of the marine sponge $A$. cornuta in different concentrations $(7,14,21,28,35$ and 42 $\mu \mathrm{g} / \mathrm{ml}$ ), and its nine column fractions with $10 \mu \mathrm{g} / \mathrm{ml}$ and different concentrations of the $9^{\text {th }}$ column fraction (Bromopyrrole compounds) ( 1 , $3,9,12,15,18$ and $21 \mu \mathrm{g} / \mathrm{ml}$ ) were subjected to MTT assay. $1 \mathrm{ml}$ of MCF7 cell suspension $\left(10^{5} \mathrm{cells} / \mathrm{ml}\right)$ were seeded in each well and incubated at $37{ }^{\circ} \mathrm{C}$ for $48 \mathrm{~h}$ in $5 \% \mathrm{CO}_{2}$ for the formation of a confluent monolayer. $200 \mu \mathrm{l}$ of MTT ( $5 \mathrm{mg} / \mathrm{ml}$ ) solution and $1 \mathrm{ml}$ of DMSO with a particular concentration of the extract were added to each well and left for $45 \mathrm{sec}$. Controls were maintained with only DMSO throughout the experiment. Absorbance was measured at $570 \mathrm{~nm}$ with an ELISA plate reader. The bromopyrrole alkaloid concentrations required to inhibit growth by $50 \%\left(\mathrm{IC}_{50}\right)$ were calculated.

\section{RESULTS}

The crude methanol extract of the marine sponge Acanthostylotela cornuta showed dose-dependent cytotoxic activity against MCF-7 cells (fig. 1). Out of nine column fractions, 9th column fraction showed the highest activity of $52 \%$ inhibition of cells at $10 \mu \mathrm{g} / \mathrm{ml}$ concentration (fig. 2). The activity of 9th column fraction was dose-dependent and the IC50 value of the9th column fraction (bromopyrrole compounds) concentration inhibiting the mean growth value by $50 \%$ was calculated as $8.0 \mu \mathrm{g} / \mathrm{ml}$ (fig. 3). GCMS spectrum of the bioactive 9th column fraction showed molecular ions at $\mathrm{m} / \mathrm{z} 225,190$ and 268 suggesting the presence of 2-Bromo-6-chloro-4-fluoroaniline, 5-bromopyrrole-2-carboxylic acid and 3-Acetyl, 6-bromocoumarin respectively, with reference to previous literature of GC-MS library (fig. 4).

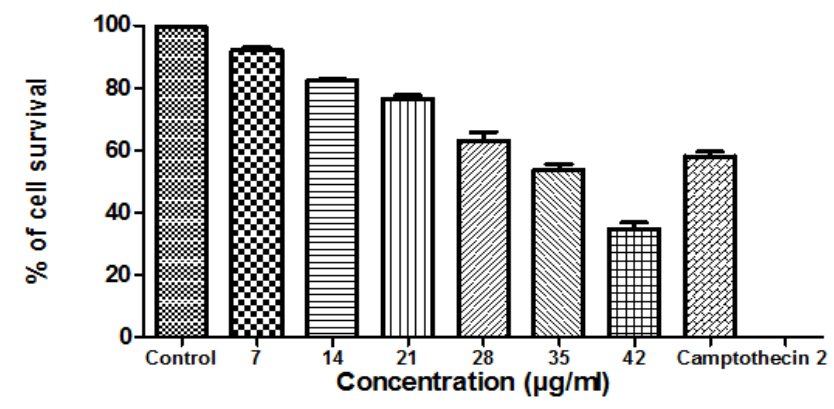

Fig. 1: Dose-dependent cytotoxicity of crude methanol extracts of marine sponge Acanthostylotela cornuta against MCF-7 cells in $24 \mathrm{~h}$ in MTT assay (bars represent mean \pm SD of three replicates) 


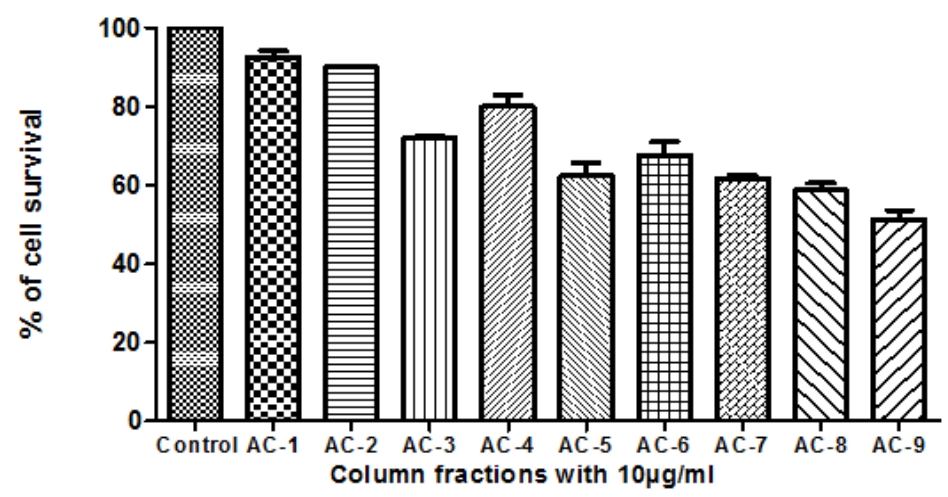

Fig. 2: Cytotoxicity of column fraction of marine sponge Acanthostylotela cornuta against MCF-7 cells in $24 \mathrm{~h}$ in MTT assay

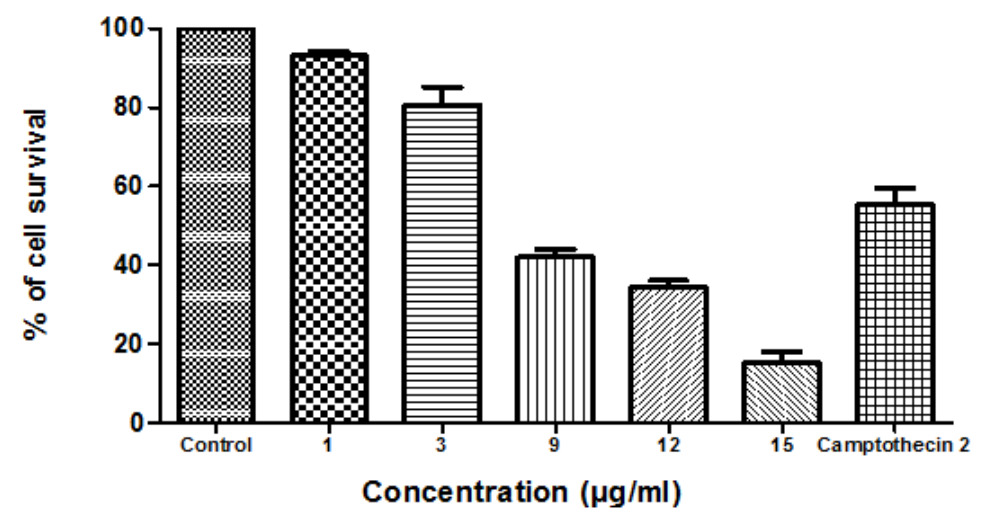

Fig. 3: Dose-dependent cytotoxicity of column fraction AC-9 (bromopyrrole compounds) of marine sponge Acanthostylotela cornuta against MCF-7 cells in $24 \mathrm{~h}$ in MTT assay

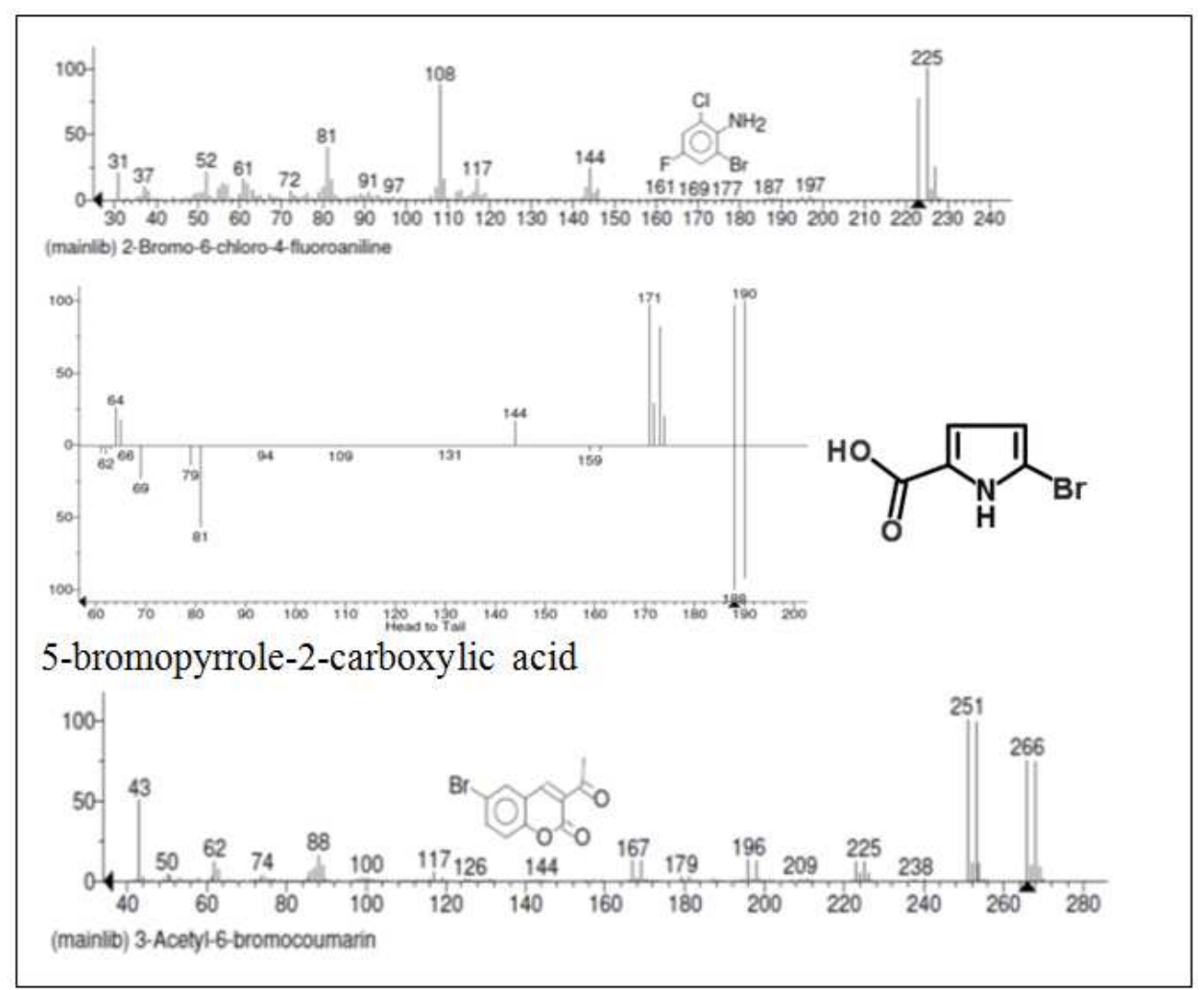

Fig. 4: GCMS spectrum of bromopyrrole compounds 
Agarose gel of electrophoresis of the DNA Fragmentations of MCF-7 breast tumour cells treated with different concentrations of bromopyrrole compounds such as 6, 7, 8, 9, 10 and $11 \mu \mathrm{g} / \mathrm{ml}$ (Lane L1, L2, L3, L4 and L5) was performed (fig. 5). Fragmented DNA showed a ladder-like pattern while Lane $M$ was the molecular marker and lane $C$ was the negative control (untreated cells). Lane L3 showed high ladder pattern of DNA of the treated MCF-7 breast tumour cells at the concentration of $8 \mu \mathrm{g} / \mathrm{ml}$, whereas, L2 and L4 showed low ladder patterns of DNA of the Bromopyrrole compounds treated MCF-7 breast tumour cells at 7 and $9 \mu \mathrm{g} / \mathrm{ml}$ respectively.

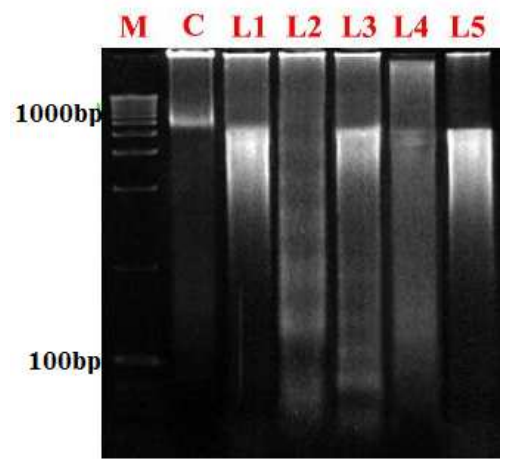

Fig. 5: DNA fragmentation analysis in MCF-7 breast tumour cells treated with bromopyrrole compounds for $24 \mathrm{~h}$; Molecular weight(Lane M) marker 500 bp DNA ladder

The bromopyrrole compounds treated and untreated cells were stained using Annexin- $\mathrm{V}$ and morphologies were immediately observed using fluorescence microscopy. Cells treated with $8 \mu \mathrm{g} / \mathrm{ml}$, showed an increase in both propidium iodide positive dead cells (Red colour), Annexin-V fluorescein isothiocyanate (FITC) positive cells (green colour), and cells which are both propidium iodide and Annexin-V FITC positive (scatted greens orange) indicating that treatment with the bromopyrrole compounds in MCF-7 cells causes apoptosis (fig. 6)

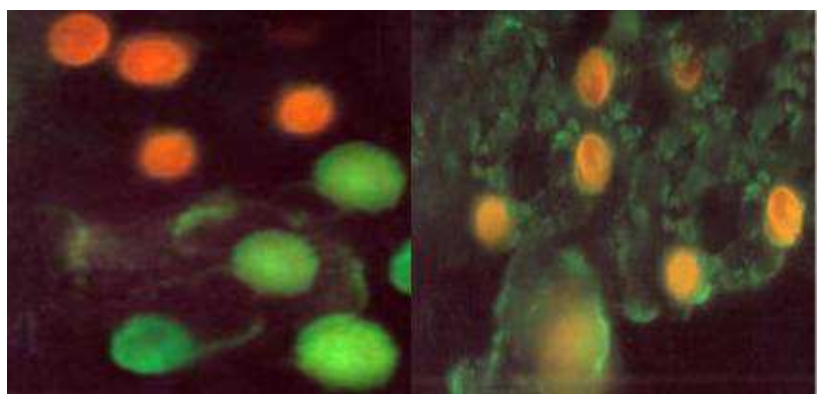

Fig. 6: Bromopyrrole compounds induces apoptotic morphological changes in MCF-7 cells

The bromopyrrole compounds treated and untreated cells were stained by Hoechst and morphologies were immediately observed using confocal microscopy. Untreated control cells exhibited bluenuclei, whereas $8 \mu \mathrm{g} / \mathrm{ml}$ of the bromopyrrole compounds treated cells exhibited blue-nucleus with fluorescence, showing condensed chromatin and DNA fragmentation as bright blue areas (fig. 7).

The bromopyrrole compounds induces apoptotic morphological changes in MCF-7 cells treated with $8 \mu \mathrm{g} / \mathrm{ml}$ for $24 \mathrm{~h}$ and the cells were stained by Propidium iodide and morphologies were immediately observed using confocal microscopy. The bromopyrrole compounds induced cells exhibited scatted red fluorescence, showing the presence of several residual bodies and condensation of chromatin (fig. 8). The low percentage of cells with apoptotic nuclei in control cultures did not result in detectable changes.

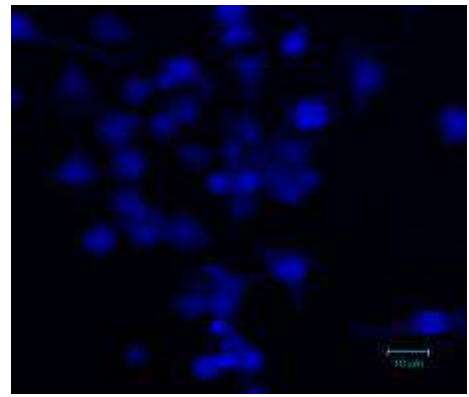

Untreated cell

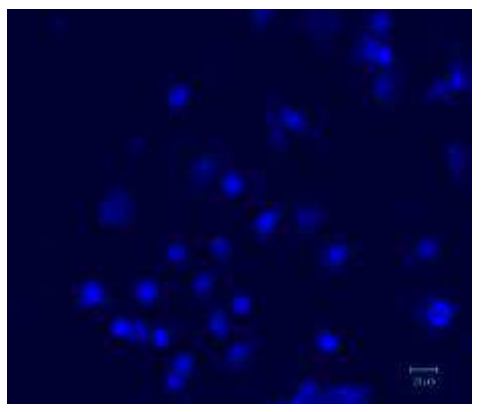

BP treated cell

Fig. 7: Bromopyrrole compounds induces DNA fragmentation and chromatin condensation in MCF-7 cells

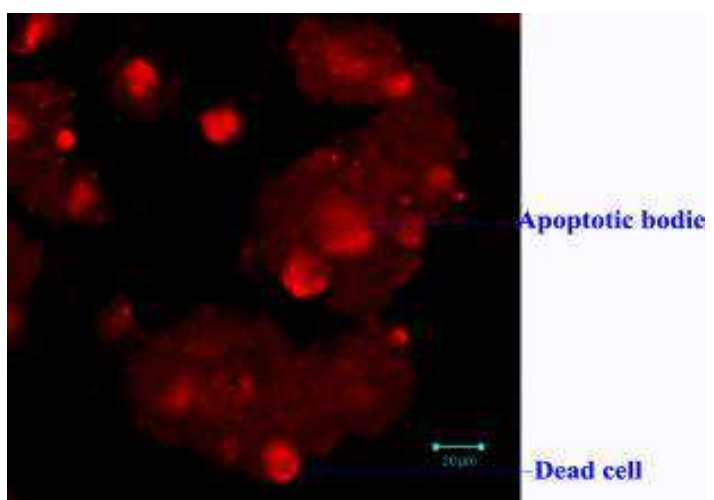

Fig. 8: Bromopyrrole compounds induces apoptotic bodies in MCF-7 cells

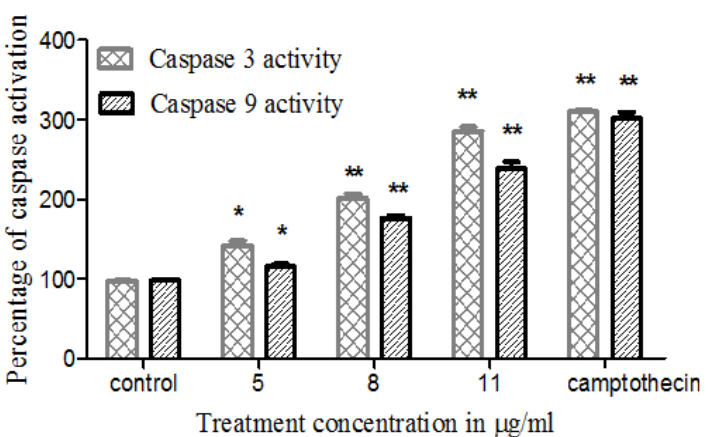

Fig. 9: Activities of caspases-3 and caspases-9 in MCF-7 breast tumour cells (bars represent mean \pm SD of three replicates; *P<0.05; ** $\mathrm{P}<0.005$ ) 
The percentages of caspase- 3 activities of treated MCF- 7 breast tumour cells were 141.6, 201 and 285.3 in 5,8 and $11 \mu \mathrm{g} / \mathrm{ml}$ respectively (fig. 9). The percentages of caspase- 9 activity of treated MCF-7 breast tumour cells were 115.3, 176 and 238.66 in 5, 8 and $11 \mu \mathrm{g} / \mathrm{ml}$ respectively. Statistical analysis between treatments with $\mathrm{IC}_{50}(8 \mu \mathrm{g} / \mathrm{ml})$ concentration and without inhibitor (control cells) using paired two-tailed Student's $t$-test with $P$-values $<0.05$ were considered as significant. The significant caspase activities of the tumour cells were comparable to the standard antibiotic camptothecin $(10 \mu \mathrm{g} / \mathrm{ml})$.

Detection of caspase-3, procaspase-9, caspase-9 and PARP were performed by Western blot analysis which showed $17 \mathrm{kDa}, 46 \mathrm{kDa}$, $37 \mathrm{kDa}$ and $85 \mathrm{kDa}$ fragments of the active-3, procaspase-9, caspase9 and PARP formed upon treatment of MCF-7 breast tumour cells with bromopyrrole compounds. Western blot analysis of caspase-3, procaspase-9, caspase- 9 and PARP activation of MCF-7 breast tumour cells treated with two different concentrations via 7 and $8 \mu \mathrm{g} / \mathrm{ml}$ (Lane L1 and L2) was performed. Caspase-3, procaspase-9, caspase-9 and PARP activity levels were higher in $7 \mu \mathrm{g} / \mathrm{ml}$ whereas activity level was lower in $8 \mu \mathrm{g} / \mathrm{ml}$ (fig. 10).

Apoptosis characteristics were further verified by Fluorescence Activated cell sorter (FACS) analysis, which showed the presence of apoptotic peak in sub-Go/G1 and Go/G1 phases (fig. 11). MCF-7 cells treated with 6,8 , and $10 \mu \mathrm{g} / \mathrm{ml}$ of the bromopyrrole compounds displayed a dose-dependent. Accumulation of apoptotic cells and the apoptosis percentage of cells at the sub $\mathrm{G}_{0} / \mathrm{G}_{1}$ population increased by $1.82 \%, 7.2 \%$ and $8.35 \%$ respectively as compared to the untreated control (2.3\%). Similarly, the apoptosis percentage of cells at the $\mathrm{G}_{0} / \mathrm{G}_{1}$ population increased by $61.72 \%, 65.9 \%$ and $67.29 \%$ respectively as compared to the untreated control (55.12\%).

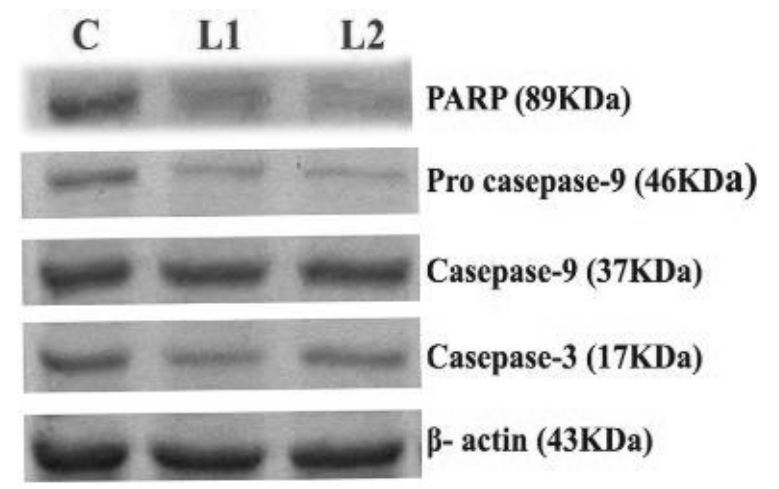

Fig. 10: Western blot analysis of caspases-3 and 9 and PARP in MCF-7 cells

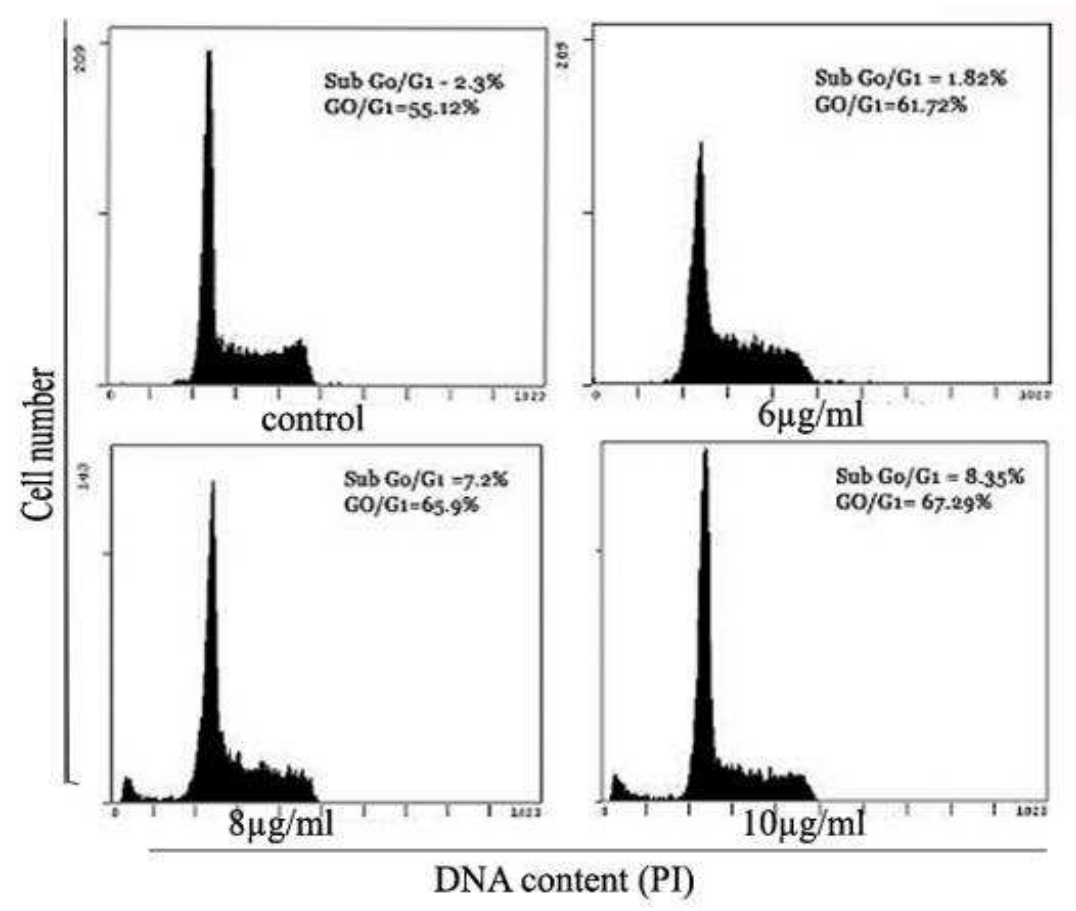

Fig. 11: Cell cycle inhibition in MCF-7 cells by the bromopyrrole compounds

\section{DISCUSSION}

Marine sponges contain a number of biodynamic compounds of therapeutic value. These compounds are providing valuable ideas for the development of new drugs against tumour. Many compounds from marine sponges have been reported to have antitumour activity in vitro [14], but there are no reports about Indian sponge Acanthostylotela cornuta against tumour cells. The results of this study indicate that there may be bromopyrrole compounds in $A$. cornuta which induce cytotoxic action against MCF-7 tumour cells and initiate cell death. The American national tumour institute guidelines have guideline for extracts at $50 \%$ inhibition ( $\mathrm{IC}_{50}$ value) of proliferation as less than $30 \mu \mathrm{g} / \mathrm{ml}[15]$. $A$. cornuta methanol extracts exhibited antitumour activity against MCF-7 tumour cells, with an IC 50 value of less than $30 \mu \mathrm{g} / \mathrm{ml}$ on the cell lines used. $\mathrm{IC}_{50}$ value of $A$. cornuta column fraction of bromopyrrole compounds as $8 \mu \mathrm{g} / \mathrm{ml}$ for MCF-7 tumour cell, though considered potent, was high when compared to $\mathrm{IC}_{50}$ of $\mathrm{IC}_{50}$ values $0.28 \mu \mathrm{g} / \mathrm{ml}$ of marine sponge Dactylia sp., which was interestingly cytotoxic against murine leukemia cell line P388 by Sato et al., [16]. This may be because, the column fraction may be only partially pure and the observation of an $\mathrm{IC}_{50}$ of $8 \mu \mathrm{g} / \mathrm{ml}$ indicated that it might yield potent and more active pure compound, as evidenced from the increase in activity from crude extract to column fraction. However, it was low $\mathrm{IC}_{50}$ when compared to the Mediterranean sponge Axinella damicornis (IC $_{50}$ of $>40 \mu \mathrm{g} / \mathrm{ml}$ ) against human cervix carcinoma HeLa S3 cells reported by Aiello et al., [17] and the Mediterranean sponge Axinella verrucosa having the $\mathrm{IC}_{50}$ of $10 \mu \mathrm{g} / \mathrm{ml}$ against PC12, HeLa, and L5178y cells reported by Aiello et al., [18]. 
The overall investigation of cytotoxic activities of the bromopyrrole compounds of $A$. cornuta revealed that, the active constituents obtained by the more polar solvent in the extraction process were responsible for the antitumor properties in this sponge. The biologically selective activity of any compound might depend on the type of chemical composition and the concentration of active constituents as well as the type and developmental stages of the tumour [19]. One of the biochemical characteristics of apoptosis is the cleavage of DNA into fragments consisting of 180-200 base pairs and the generation of typical DNA ladder on gel electrophoresis [20]. These cleavages in DNA of MCF-7 tumour cells may be induced by the bromopyrrole compounds from A. cornuta.

The present study reports, the evidence that a bromopyrrole compounds of $A$. cornuta induce apoptosis in tumor cells by caspase activation that has cytotoxic effect in vitro against tumour cells at least in part through induction of apoptosis via caspase-9 (mitochondrial) pathway. Induction of apoptosis in vitro was associated with caspase-3 activation [21]. According to Reiner et al., [22], caspase-3 was responsible for many of the morphological and biochemical features of apoptosis, where the process occurs in a systematic and deliberate manner which involves a series of activation of enzymes such as cysteine proteases (caspases) and endonucleases. The present study reveals that the bromopyrrole compounds induce apoptosis with affecting mitochondrial regulation.

According to Nicholson et al., [23] fragmentation of $116 \mathrm{kDa}$ PARP proteins into $85 \mathrm{kDa}$ fragments was the evidence of apoptosis. Results of the present study also showed that active fractions of $A$. cornuta cleaved $116 \mathrm{kDa}$ PARP protein into $85 \mathrm{kDa}$ fragments. Thus the bioactive bromopyrrole compounds in A. cornuta are capable of inducing apoptosis in MCF-7 cells via the mitochondria-mediated pathway, which results in the activation of caspase- 9 , caspase- 3 and degradation of PARP. This study also defines those events, most of which are used as biomarkers of apoptosis, that are associated with bromopyrrole compounds of $A$. cornuta induced apoptotic cell death. Activated caspase- 3 was responsible for the proteolytic degradation of poly ADP-ribose polymerase, which occurs at the onset of apoptosis [24]. It has been reported that the central mechanism of apoptosis is evolutionarily conserved, and that caspase activation is an essential step in the complex apoptotic pathway [25]. The presented data, therefore, provides important evidence that compounds of $A$. cornuta induced MCF-7 cell death in apoptosis.

The results of annexin- $V$ staining analysis revealed that the bromopyrrole compounds of $A$. cornuta induced the early stage of apoptosis due to membrane phospholipids redistributing from the inner to the outer leaflet of the membrane bilayer. One of the hallmarks of the early stage of apoptosis is that membrane phospholipids such as phosphatidyl-serine and phosphatidylethanolamine redistribute from the inner to the outer leaflet of the membrane bilayer where they are exposed on the cell surface [26]. Externalization of phosphatidylserine residues to the outer plasma membrane leaflet al. lows their detection via their high affinity for annexin- $\mathrm{V}$, a phospholipid binding protein.

The results of Hoechst staining revealed that the bromopyrole compounds of A. cornuta induced the nuclear condensation. In the same manner, the apoptosis induced by the bromopyrrole compounds of $A$. cornuta was also confirmed by staining the cells using Propidium iodide (PI) fluorescence dye. Additionally, the results of the PI staining revealed the nuclear condensation and cell fragmentation into apoptotic bodies. These distinct characteristics of apoptotic process in all the treated tumour cells suggest that the mode of cell death triggered by the bromopyrrole compounds of $A$. cornuta might be the process of apoptosis. These processes in apoptosis are recognized as a novel strategy for identification of antitumor drugs [27].

Regulation of the tumour cell cycle is one of the strategies in the development of antitumor drugs [28]. In the present study, the result of cell cycle analysis determined by flow cytometry analysis showed that the compound could arrest the cell cycle in a dosedependent manner in MCF-7 cells. The apoptotic rate contrarily increased after treatment with high concentration. The observations with cell cycle progression revealed that pre-exposure to the compound induced $\mathrm{G}_{0}-\mathrm{G}_{1}$-phase cell cycle arrest. This showed that the compound inhibited the proliferation of MCF-7 cells through the inducement of cell apoptosis. According to Ormerod et al., [29] the visibility of "sub-Go" peak (hypodiploid DNA peak) by flow cytometry with other supporting information can be taken as definite evidence for the apoptotic cell population. Results of this method of measuring apoptosis would provide stronger evidence that apoptosis indeed was induced in the cell lines after treatment with the compound. The cell cycle arrest is conceivable that the compound prevented the progression of cell cycle through the $G$ phase resulting from inhibition of survival, leading them to undergo apoptosis. The arrest of $\mathrm{G}$ phase by the bromopyrrole compounds of A. cornuta clearly indicated its nature as that of antitumor drugs.

\section{CONCLUSION}

In conclusion, the data reported here indicate that the bromopyrrole compounds of $A$. cornuta inhibits growth and proliferation by arresting the cell cycle at the G phase, and induces apoptosis in MCF7 cells. This apoptosis was mediated by the activation of intrinsic caspase cascade, in MCF-7 cells. Thus the results of the present study provide supportive data for the antitumor potential of the bromopyrrole compounds of $A$. cornuta.

\section{ACKNOWLEDGMENT}

This investigation was supported by the ISRO/SAC, MoES and Department of Marine and Coastal Studies, Madurai Kamaraj University, Madurai, Tamilnadu, India.

\section{AUTHORS CONTRIBUTIONS}

All the author have contributed equally

\section{CONFLICT OF INTERESTS}

\section{Declared none}

\section{REFERENCES}

1. Xiaoxian L, Michael TL, Jian H, Carolina G, Kent OC, Meng-Fen $\mathrm{W}$, et al. Intrinsic resistance of tumorigenic breast cancer cells to chemotherapy. J Nat Cancer Inst 2008;100:672-9.

2. Manikandan S, Ganesapandian S, Manoj S, Kumaraguru AK. Emerging of multidrug resistance human pathogens from urinary tract infection. Curr Res Bacteriol 2011a;4:9-15.

3. Manikandan S, Ganesapandian S, Manoj S, Kumaraguru AK. Antimicrobial susceptibility pattern of Urinary Tract Infection causing human pathogenic bacteria. Asian J Med Sci 2011b;3:56-60.

4. Ramesh S, Dilipan E, Mayavu P. Effects of drugs against antioxidant and cytotoxic (hep 2 cell line) activity compounds from marine animals Conus amadis venom (GMELIN, J. F, 1791). Int J Pharm Pharm Sci 2014;6:638-43.

5. Ramasamy MS, Manikandan S. Novel pharmacological targets from Indian cone snails. Mini Rev Med Chem 2011;1:125-30.

6. Manikandan S, Ganesapandian S, Manoj S, Sangeetha N, Kumaraguru AK. Antimicrobial activity of seaweeds against multi-drug resistant strains. Int J Pharm 2011c;7:522-6.

7. Salini G. Pharmacological profile of mangrove endophytes-a review. Int J Pharm Pharm Sci 2015;7:6-15.

8. Bailly C. Ready for a comeback of natural products in oncology. Biochem Pharm 2009;77:1447-57.

9. Rinehart KL, Holt TG, Fregeau NL, Stroh JG, Keifer PA, Sun F, et al. Ecteinascidin-729, ecteinascidin-743, ecteinascidin-745, ecteinascidin-759a, ecteinascidin-759b, and ecteinascidin-770potent antitumor agents from the Caribbean Tunicate Ecteinascidia-Turbinata. J Org Chem 1990;55:4512-5.

10. Dembitsky VM. Bromo and iodo-containing alkaloids from marine microorganisms and sponges. Russ J Bioorgan Chem 2002;28:170-82.

11. Thomas PA. Porifera. In: Faunal Diversity in India. Alfred JRB, Das AK, Sanyal AK. (Eds.). ENVIS Center, Zoological survey of India, Culcutta; 1998. p. 28-36.

12. Mosmann T. Rapid colorimetric assay for cellular growth and survival: application to proliferation and cytotoxicity assays. J Immunol Methods 1983;65:55-63.

13. Connor PM, Wasserman K, Sarang M, Magrath I, Bohr VA, Kohn KW. Relationship between DNA cross-links, cell cycle, and 
apoptosis in Burkitt's lymphoma cell lines differing in sensitivity to nitrogen mustard. Tumor Res 1991;51:6550-7.

14. Luke ST, Eric A, Kerry M, Patricia F, Gerwick WH. Marine natural products as anticancer drugs. Mol Cancer Ther 2005;4:333-42.

15. Rajesh RP, Ramasamy MS, Murugan A. Anticancer activity of the ascidian polyclinum indicum against cervical cancer cells (HeLa) mediated through apoptosis induction. Med Chem 2010;6:396-405.

16. Sato S, Makoto K, Noboru O. Ircinamine B, a bioactive alkaloid from marine sponge Dactylia sp. Tetrahedron Lett 2006;47:7871-3.

17. Aiello A, Monica D, Ernesto F, Marialuisa M, Werner E, Muller G, et al. A bioactive pyrrole alkaloid from the Mediterranean sponge Axinella damicornis. Tetrahedron 2005;61:7266-70.

18. Aiello A, Monica D, Ernesto F, Marialuisa M, Werner E, Muller G, et al. Novel bioactive bromopyrrole compounds from the Mediterranean sponge Axinella verrucosa. Bioorgan Med Chem 2006;14:17-24.

19. Elena I, Miguel H, Jose AM, Maria CP. Extraction and characterization of bioactive compounds with health benefits from marine resources: macro and microalgae, cyanobacteria, and invertebrates. Marine bioactive compounds: Sources, characterization and applications; 2012. p. 55-98.

20. Saraste A, Pulkki K. Morphologic and biochemical hallmarks of apoptosis. Cardiovas Res 2000;45:528-37.

21. Magali P, Chahrazade K, Valerie G, Sandra M, Veronique W. Proteinase-3 induces procaspase-3 activation in the absence of apoptosis: potential role of this compartmentalized activation of membrane-associated procaspase-3 in neutrophils. J Immunol 2005;174:6381-90.
22. Reiner UJ, Michael LS, Mas RW, Alan GP. Caspase-3 is required for DNA fragmentation and morphological changes associated with apoptosis. J Biol Chem 1998;273:9357-60.

23. Nicholson DW, Ali A, Thornberry NA, Vaillancourt JP, Ding CK, Gallant M. Identification and inhibition of the ICE/CED-3 protease necessary for mammalian apoptosis. Nature 1995;376:37-43.

24. Lazebnik YA, Kaufmann SH, Desnoyers S, Poirier GG, Earnshaw WC. Cleavage of poly (ADP-ribose) polymerase by a proteinase with properties like ICE. Nature 1994;371:346-7.

25. Imawati B, Holt O, Michael L, Xu L, Xiaodong W. Biochemical pathways of caspase activation during apoptosis. Annu Rev Cell Dev Biol 1999;15:269-90.

26. Elmore S. Apoptosis: a review of programmed cell death. Toxicol Pathol 2007;35:495-516.

27. Jiang $\mathrm{S}$, Yuan WZU, Yue JFU, Zhang Y, Thomas E. Activation of the mitochondria-driven pathway of apoptosis in human PC-3 prostate tumour cells by a novel hydrophilic paclitaxel derivative, 7-xylosyl-10-deAcetylpAclitaxel. Int J Oncol 2008;33:103-11.

28. Katrien V, Dirk RVB, Zwi NB. The cell cycle: a review of regulation, deregulation and therapeutic targets in cancer. Cell Prolif 2003;36:131-49.

29. Ormerod MG, Collins MKL, Rodriguez Tarduchy G, Robertson D. Apoptosis in interleukin-3 dependent haemopoietic cells: Quantification by two flow cytometric methods. J Immunol Methods 1992;153:57-65. 